\title{
IDENTIFIKASI MISKONSEPSI MATERI MEKANIKA DENGAN MENGGUNAKAN CRI (CERTAINTY OF RESPONSE INDEX)
}

\author{
Venny Haris \\ Program Studi Tadris Fisika Jurusan Tarbiyah STAIN Batusangkar \\ Jl. Sudirman No. 137 Kuburajo Lima Kaum Batusangkar, Sumatera Barat 27213 \\ e-mail: venny_haris@yahoo.com
}

\begin{abstract}
It has been done a descriptive quantitative research about The identification of mechanical Misconception Concept by Using CRI (Certainty of Response Index). This research was applied to the first semester students of Physical Science Department of STAIN Batusangkar who were registered in 2011/2012 academic year that consisted of 55 students. In collecting the data, the instrument of this research was test in multiple choice form. It consisted 30 items. In asnwering the question, the students were asked to write CRI mark (0-5) as level of their believe to their answer. A misconception student can be known by comparing his or her answer based on CRI s/he fills. Research result showed that $80 \%$ students did misconception of the time concept of free falling bodies, $45 \%$ students did not know the concept of action (aksi) and reaction (reaksi), and $7.27 \%$ students knew the concept of Newton Formula 1. It can be concluded that the level of misconception of the first semester students of Physical Science Department of STAIN Batusangkar who were registered in 2011/2012 academic year was very high.
\end{abstract}

Kata kunci: miskonsepsi fisika, instrumen, mekanika, CRI (Certainty of Response Index)

\section{PENDAHULUAN}

I lmu Fisika merupakan bagian dari ilmu pengetahuan alam dan memiliki peran yang sangat penting dalam perkembangan ilmu pengetahuan dan teknologi. Mengingat begitu pentingnya peranan ilmu fisika, maka sudah semestinya ilmu ini dipahami dengan baik oleh mahasiswa yang mempelajari fisika itu. Berdasarkan pengalaman penulis dalam mengajar mata kuliah fisika dasar untuk mahasiswa prodi pendidikan MIPA (prodi tadris Matematika, prodi tadris Fisika, prodi tadris Biologi) STAIN Batusangkar, didapatkan masih banyak terjadi miskonsepsi mahasiswa terhadap materi fisika yang telah mereka pelajari. Para mahasiwa, sebelum mengikuti proses pembelajaran fisika secara formal di kampus sudah membawa konsep awal tentang fisika. Konsep awal yang mereka bawa itu kadang-kadang tidak sesuai atau bertentangan dengan konsep yang diterima para ahli. Hasil pengamatan yang telah penulis lakukan saat proses pembelajaran, terhadap mahasiswa program studi tadris fisika STAIN Batusangkar adalah masih ditemukan mahasiswa yang beranggapan bahwa benda yang massa nya lebih besar akan mencapai tanah lebih awal dari pada benda yang massanya lebih kecil pada gerak jatuh bebas. Konsep awal yang tidak sesuai dengan konsep ilmiah 
inilah yang disebut dengan miskonsepsi atau salah konsep (Suparno,2005). Banyak hal yang bisa menyebabkan terjadinya miskonsepsi ini. Salah satunya adalah pengalaman sehari-hari ketika berinteraksi dengan alam sekitar. Seperti, mereka sudah memiliki pengalaman dengan peristiwa gerak jatuh bebas, energi, tumbukan, aliran listrik, dan lain-lain. Guru atau tenaga pengajar juga bisa menjadi salah satu penyebab terjadinya miskonsepsi. Misalnya guru atau tenaga pengajar yang tidak menguasai konsep fisika.

Miskonsepsi yang terdapat pada mahasiswa program studi pendidikan fisika dapat menyebabkan salah kaprah dalam dunia pendidikan fisika jangka panjang. Karena tidak jarang miskonsepsi yang terjadi ini bertahan lama dan sulit diperbaiki. Menurut Klammer (Tayubi, Y.R.,2005), adanya miskonsepsi ini bisa menghambat pada proses penerimaan dan asimilasi pengetahuanpengetahuan baru dalam diri mahasiswa, sehingga dapat menghalangi keberhasilan proses belajar lebih lanjut.Untuk menghindari terjadinya miskonsepsi materi fisika yang berkelanjutan, maka miskonsepsi yang terdapat pada mahasiswa prodi pendidikan fisika harus diidentifikasi dan diperbaiki sedini mungkin. Sehingga konsep yang salah terhadap materi fisika bisa diperbaiki dari tahun awal perkuliahan. Hal ini sangat penting, salah satunya adalah karena mahasiswa prodi pendidikan fisika merupakan calon guru fisika. Sehingga diharapkan ketika mereka jadi guru nanti, dapat membantu siswa dengan metode yang lebih tepat dengan konsep fisika yang benar.

Usaha untuk mengidentifikasi miskonsepsi sudah banyak dilakukan oleh peneliti sebelumnya (Halloun dan
Hestenes, 1985; Hestenes, dkk.,1992; Osterholm, M.,2000; Heon, dkk., 2005; Muller, dkk.,2007). Namun hingga saat ini masih terdapat kesulitan dalam membedakan antara mahasiswa yang mengalami miskonsepsi dengan yang tidak tahu konsep. Tanpa dapat membedakan diantara keduanya, akan sulit untuk menentukan langkah penanggulangannya. Sebab penanggulangan mahasiswa yang mengalami miskonsepsi akan berbeda dengan mahasiswa yang tidak tahu konsep. Sebagai salah satu alternatif yang digunakan untuk mengidentifikasi miskonsepsi adalah teknik Certainty of Response Index (CRI) yang dikembangkan oleh Hasan, S.,dkk (1999). Certainty of Response Index (CRI) adalah salah satu cara untuk membedakan miskonsepsi dengan yang tidak tahu konsep. Penelitian Masril dan Asma (2002) menggunakan Certainty of Response Index (CRI) untuk membedakan antara siswa yang mengalami miskonsepsi dengan yang kurang pengetahuan (lack of knowledge) terhadap soal-soal Force Concept Inventory (FCI). Perbedaan ditentukan berdasarkan tingkat keyakinan siswa terhadap pilihannya yang ditandai dengan nilai CRI yang diberikan pada lembar jawaban. Penelitian yang hampir sama dilakukan oleh Tayubi, Y.R (2005) untuk mengidentifikasi miskonsepsi pada konsep-konsep fisika menggunakan Certainty of Response Index (CRI).

CRI biasanya berdasarkan pada suatu skala yang tetap, misalnya skala sebelas ataupun skala enam. Dalam penelitian ini skala yang digunakan adalah skala enam (0-5) yang dikemukakan oleh Hasan, S.,dkk (1999) sebagai berikut: 
Tabel 1. CRI dan kriterianya

\begin{tabular}{cl}
\hline CRI & \multicolumn{1}{c}{ Kriteria } \\
\hline 0 & $\begin{array}{l}\text { (Totally guessed answer) } \\
\text { Jika dalam menjawab soal 100\% ditebak } \\
\text { (Almost guess) }\end{array}$ \\
1 & $\begin{array}{l}\text { Jika dalam menjawab soal presentase unsur tebakan antara 75\% - 99\% } \\
\text { (Not sure) }\end{array}$ \\
3 & $\begin{array}{l}\text { Jika dalam menjawab soal presentase unsur tebakan antara 50\% - 74\% } \\
\text { (Sure) } \\
\text { Jika dalam menjawab soal presentase unsur tebakan antara 25\% - 49\% } \\
\text { (Almost certain) } \\
\text { Jika dalam menjawab soal presentase unsur tebakan antara 1\% - 24\% } \\
\text { (Certain) } \\
\text { Jika dalam menjawab soal tidak ada unsur tebakan sama sekali (0\%) }\end{array}$ \\
\hline
\end{tabular}

Penelitian ini telah dilaksanakan dengan memilih topik mekanika, yang diterapkan pada mahasiswa tahun pertama program studi Tadris Fisika STAIN Batusangkar. Pemilihan topik mekanika pada penelitian ini karena secara umum mekanika merupakan bagian ilmu fisika yang dekat dengan kehidupan seharihari. Selain itu berdasarkan penelitian sebelumnya, jumlah miskonsepsi materi mekanika yang ditemukan pada siswa dan mahasiswa cukup banyak (Halloun dan Hestenes, 1985; Hestenes, dkk.,1992; Osterholm, M.,2000; Masril dan Asma, 2002; Demirci, 2005). Sehingga untuk tahap awal telah dilakukan identifikasi dan analisis miskonsepsi terhadap materi mekanika pada mata kuliah Fisika Dasar.

Tujuan dari penelitian ini adalah untuk mengidentifikasi miskonsepsi pada materi mekanika, sampai dapat dibedakan mahasiswa yang mengalami miskonsepsi, tidak tahu konsep, dan menguasai konsep dengan baik. Hasil identifikasi kemudian dianalisis sehingga dapat diketahui hal-hal yang menjadi miskonsepsi pada materi mekanika.

\section{METODOLOGI PENELITIAN}

\section{Jenis Penelitian}

Penelitian ini merupakan jenis penelitian desriptif kuantitatif . Menurut Sugiyono (2007), yang dimaksud dengan penelitian deskriptif adalah penelitian dengan cara membuat deskripsi/gambaran/lukisan secara sistematis, faktual, dan aktual mengenai fakta-fakta.

\section{Subjek Penelitian}

Subjek penelitian ini adalah mahasiswa program studi Tadris/Pendidikan Fisika semester 1 STAIN Batusangkar yang berjumlah 55 orang mahasiswa (Akama, 2011). Pemilihan mahasiswa semester 1 Prodi Tadris/Pendidikan Fisika sebagai responden dilakukan dengan alasan para mahasiswa ini sudah memiliki latar belakang ilmu fisika yang sama yang telah diperoleh dari bangku sekolah menengah. Jadi mahasiswa ini dianggap telah mendapatkan materi mekanika SMA secara keseluruhan, dan selayaknya mampu untuk menjawab soal-soal mekanika untuk fisika dasar karena sebelum memasuki Perguruan Tinggi mereka sudah disiapkan untuk menempuh Ujian Akhir Nasional. Dalam standar kurikulum nasonal, mekanika merupakan bahan pelajaran kelas $\mathrm{X}$ dan kelas XI (KTSP Mata Pelajaran Fisika untuk SMA dan MA, 2005).

\section{Teknik Pengumpulan Data}

Untuk melaksanakan penelitian dan memperoleh data yang dibutuhkan, perlu ditentukan alat pengumpul data. 
Alat pengumpul data yang digunakan adalah tes tertulis pilhan ganda. Tes ini digunakan untuk mengidentifikasi dan membedakan mahasiswa yang mengalami miskonsepsi, tidak tahu konsep, dan menguasai konsep dengan baik dengan menggunakan teknik CRI. Jumlah pertanyaan (soal) yang digunakan adalah 30 soal materi mekanika dengan jumlah pilihan sebanyak 5. Pertanyaanpertanyaan yang diberikan dirancang sedemikian rupa agar pertanyaan ini bersifat kualitatif yang standar (tidak memiliki tingkat kesulitan yang tinggi), dan dianggap dapat menguji pemahaman konsep mahasiswa karena berisikan materi-materi dasar yang sudah dipelajari oleh mahasiswa tersebut di bangku sekolah menengah. Sampel yang terdiri dari mahasiswa semester 1 ini dianggap sudah mendapatkan pendidikan fisika yang minimum standar dari guru fisika mereka di sekolah menengah, sehingga jika siswa tidak mampu menjawab pertanyaan-pertanyaan tes dengan benar, dapat diasumsikan sudah terjadi miskonsepsi pada mahasiswa tersebut.

Tabel 1.Instrumen Tes Soal Pilihan Ganda yang Diuji Pemahaman Konsepnya

\begin{tabular}{|c|c|c|}
\hline $\begin{array}{l}\text { Ruang Lingkup } \\
\text { Fisika yang } \\
\text { Berkaitan }\end{array}$ & Konsep-konsep Mekanika yang Diujikan & $\begin{array}{l}\text { Nomor Pertanyaan pada } \\
\text { Instrumen }\end{array}$ \\
\hline \multirow{9}{*}{$\begin{array}{l}\text { Kinematika gerak } 1 \\
\text { dimensi }\end{array}$} & Pemahaman konsep jarak dan perpindahan & 1,2 \\
\hline & $\begin{array}{l}\text { Konsep posisi dirancukan dengan kecepatan } \\
\text { (Jika dua objek memiliki posisi yang sama, } \\
\text { maka mereka harus juga mempunyai kecepatan } \\
\text { yang sama). }\end{array}$ & 3 \\
\hline & Ungkapan kelajuan konstan & 4,5 \\
\hline & Konsep arah percepatan dan kecepatan & 6 \\
\hline & $\begin{array}{l}\text { Konsep kecepatan suatu benda nol tidak selalu } \\
\text { mengakibatkan percepatan juga nol }\end{array}$ & 7 \\
\hline & Konsep kelajuan sama dengan kecepatan & 8 \\
\hline & $\begin{array}{l}\text { Konsep kecepatan dan percepatan pada gerak } \\
\text { vertikal ke atas }\end{array}$ & 9,10 \\
\hline & Konsep waktu jatuh pada gerak jatuh bebas & 11 \\
\hline & $\begin{array}{l}\text { Konsep kecepatan dan percepatan pada gerak } \\
\text { jatuh bebas }\end{array}$ & 12,13 \\
\hline \multirow{2}{*}{$\begin{array}{l}\text { Kinematika gerak } \\
\text { dalam dua dimensi } \\
\text { (gerak peluru) }\end{array}$} & $\begin{array}{l}\text { Konsep besar kecepatan pada suatu puncak } \\
\text { proyektil }\end{array}$ & 14 \\
\hline & Bentuk lintasan pada gerak peluru & 15 \\
\hline \multirow{5}{*}{$\begin{array}{l}\text { Gerak dan Gaya } \\
\text { (Dinamika) }\end{array}$} & Konsep hukum Newton 1 & 16,19 \\
\hline & Konsep gaya normal dan gaya berat & 20 \\
\hline & Konsep gaya aksi dan reaksi & 17 \\
\hline & $\begin{array}{l}\text { Konsep tentang gaya (benda yang diam berarti } \\
\text { tidak mengalami gaya) }\end{array}$ & 18 \\
\hline & $\begin{array}{l}\text { Gaya gesekan hanya tergantung pada kekasaran } \\
\text { permukaan }\end{array}$ & 21 \\
\hline $\begin{array}{l}\text { Momentum dan } \\
\text { Impuls }\end{array}$ & Konsep impuls & 26,28 \\
\hline \multirow[t]{4}{*}{ Kerja dan Energi } & Konsep kerja/usaha & 22,23 \\
\hline & Konsep energi potensial & 24 \\
\hline & $\begin{array}{l}\text { Energi kinetik benda berhubungan secara linear } \\
\text { dengan kecepatan benda }\end{array}$ & 25 \\
\hline & Konsep energi potensial gravitasi & 27 \\
\hline Gerak Rotasi & $\begin{array}{l}\text { Konsep energi kinetik rotasi yang dimiliki oleh } \\
\text { benda yang mengalami gerak translasi }\end{array}$ & 29,30 \\
\hline
\end{tabular}




\section{Analisis Data}

Data yang telah terkumpul dianalisis serta diidentifikasi mahasiswa yang mengalami miskonsepsi, tidak tahu konsep, dan menguasai konsep dengan baik dengan teknik CRI yaitu dengan langkah-langkah berikut (Liliawati dan Ramalis, 2008):

1. Mengidentifikasi miskonsepsi pada setiap konsep materi mekanika yang terjadi pada setiap mahasiswa secara perorangan. Langkah-langkahnya adalah: (1) Melakukan penskoran dan tabulasi indeks CRI untuk setiap mahasiswa; (2) Menentukan mahasiswa-mahasiswa yang tahu konsep, miskonsepsi dan tidak tahu konsep; (3) Mentabulasi persentasi mahasiswa yang tahu konsep, miskonsepsi, dan tidak tahu konsep pada setiap konsep yang diujikan; (4) Membuat grafik yang melukiskan perbandingan persentase mahasiswa yang mengalami miskonsepsi, dan tidak tahu konsep pada setiap soal yang diberikan.

2. Mengidentifikasi miskonsepsi pada setiap konsep yang terjadi pada setiap kelompok mahasiswa. Langkah-langkahnya adalah: (1) Mencari rata-rata CRI jawaban benar dan jawaban salah dari setiap konsep yang diujikan;

(2) Menentukan fraksi mahasiswa yang menjawab benar atau fraksi mahasiswa yang menjawab salah dari total seluruh mahasiswa; (3) Membuat grafik yang melukiskan perbandingan rata-rata CRI jawaban benar dan salah dengan fraksi jumlah mahasiswa yang menjawab benar pada setiap soal yang diberikan; (4) Menentukan konsepsi kelompok siswa terhadap setiap konsep untuk menentukan kecendrungan miskonsepsi atau tidak tahu konsep.

\section{HASIL DAN PEMBAHASAN}

\section{Identifikasi Miskonsepsi Materi Mekanika}

\section{Identifikasi Konsepsi Siswa Secara Perorangan}

Setelah melakukan langkah-langkah yang harus ditempuh pada proses pengolahan data maka didapatkan hasil sebagai berikut: berdasarkan hasil penelitian, skor tertinggi adalah 13 dan terendah adalah 4. Jumlah yang benar terbanyak pada soal nomor 26 dan jumlah salah terbanyak pada soal nomor 28. Berdasarkan hal tersebut, maka dapat dianalisa bahwa konsep pengertian impuls sudah dikuasai dibanding dengan konsep-konsep lainnya, dan konsep mengenai impuls bukan merupakan sesuatu hal yang dimiliki benda belum dikuasai oleh mahasiswa mengingat jumlah siswa yang menjawab benar paling sedikit dibanding dengan konsep-konsep lainnya.

Setelah melakukan penskoran dan tabulasi nilai CRI, maka dapat diketahui mahasiswa-mahasiswa yang tidak tahu konsep, miskonsepsi dan tahu konsep. Hasil tabulasi persentase mahasiswa yang tahu konsep, tidak tahu konsep, dan miskonsepsi pada setiap soal/konsep mekanika yang diujikan disajikan pada Gambar 1. Pada Gambar 1 dapat dilihat bahwa miskonsepsi paling banyak yaitu sebesar $80,00 \%$ terdapat pada soal no 3 mengenai konsep posisi dan kecepatan dan soal no 11 mengenai konsep waktu jatuh pada gerak jatuh bebas. Sedangkan miskonsepsi paling sedikit terdapat pada soal no 26 mengenai impuls sebesar 9,09\%. Pada soal no 26 ini mahasiswa yang tahu konsep cukup banyak sekitar $70,91 \%$ dari 55 orang mahasiswa. Berikutnya miskonsepsi yang cukup tinggi juga ditemukan pada soal no 2 mengenai konsep jarak dan perpindahan. Sekitar $70,91 \%$ mahasiswa tidak tahu konsep 
jarak dan perpindahan. Pada soal no 2 ini, mahasiswa yang tahu konsep juga sedikit yaitu sekitar $9,09 \%$ dari 55 orang mahasiswa. Sekitar $65,45 \%$ mahasiswa juga mengalami miskonsepsi pada konsep Hukum Newton 1. Ini dapat dilihat pada soal no 16 dan soal no 19 . Berdasarkan Gambar 1 dapat dilihat bahwa hanya pada soal no 4,21 , dan 26 , per- sentase mahasiswa yang tahu konsep lebih banyak dibanding dengan mahasiswa yang mengalami miskonsepsi dan tidak tahu konsep. Dari gambar 1 juga ini bisa diketahui, ternyata konsep mengenai kelajuan konstan, faktor yang mempengaruhi gaya gesekan, dan pengertian impuls sudah dikuasai oleh mahasiswa dengan baik.



Gambar 1. Grafik Identifikasi Jumlah Mahasiswa yang Miskonsepsi, Tahu Konsep dan Tidak Tahu Konsep

\section{Identifikasi Konsepsi Mahasiswa Se- cara Kelompok}

Setelah melakukan langkah-langkah yang harus ditempuh pada proses pengolahan data untuk mengidentifikasi konsepsi pada kelompok, maka didapatkan hasil sebagai berikut:

Rata-rata nilai CRI yang menjawab benar dan yang menjawab salah serta fraksi mahasiswa yang menjawab benar dan fraksi mahasiswa yang menjawab salah disajikan pada Gambar 2. Berdasarkan hasil perbandingan antara CRI jawaban benar dan salah dengan fraksi jumlah mahasiswa yang menjawab benar pada setiap konsep pada grafik gambar 2, maka dapat dianalisis bahwa kelompok mahasiswa yang menjadi responden masih cenderung mengalami miskonsepsi pada setiap konsep/soal yang diujikan. Pada grafik gambar 2 misalnya untuk soal no 11 , terlihat bahwa rata-rata CRI benar cukup tinggi yaitu $>4$, yang mana berdasarkan teori berarti kelompok mahasiswa/responden tahu akan konsep. Akan tetapi dengan melihat grafik fraksi jawaban benar pada soal no 11 yang berkisar 0,04 dapat dianalisis bahwa mahasiswa yang menjawab benar dengan CRI tinggi jumlahnya sedikit. Hal yang sama juga terlihat pada soal no 28. Berdasarkan grafik juga bisa dilihat bahwa jumlah mahasiswa yang menjawab benar dengan tingkat CRI yang tinggi $(\mathrm{CRI}>2,5)$ terdapat pada soal no 4 mengenai kelajuan konstan, soal no 21 mengenai faktor yang mempengaruhi gaya gesekan, soal no 26 mengenai konsep impuls, dan soal no 29 mengenai konsep energi kinetik pada gerak rotasi. 


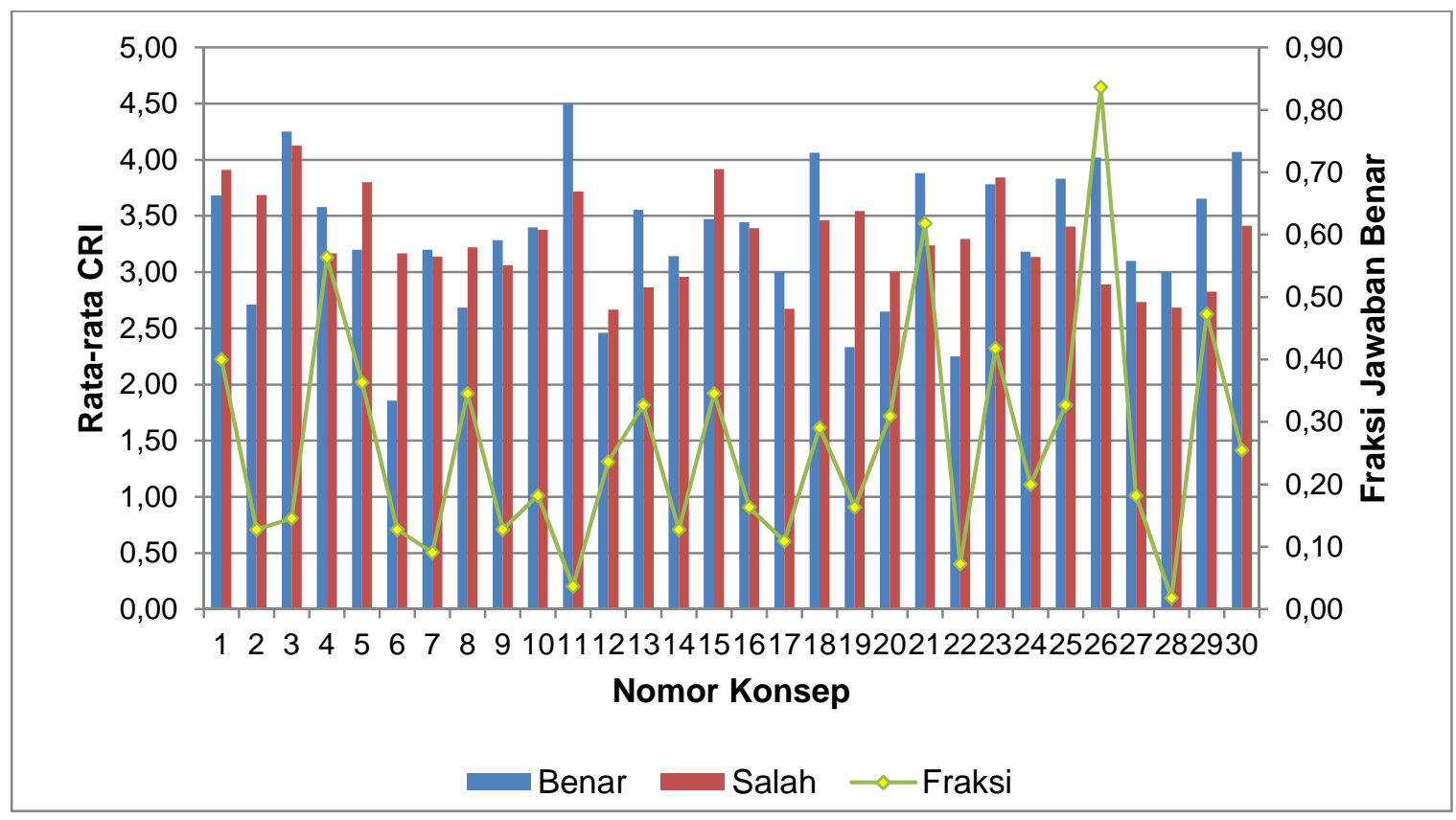

Gambar 2. Grafik Perbandingan Rata-rata CRI Jawaban Benar dan Salah dengan Fraksi Jumlah Mahasiswa yang Menjawab Benar

\section{Analisis Hasil Jawaban Mahasiswa pada Tes Konsep Mekanika}

\section{Analisis Pemahaman Mahasiswa Ter- hadap Konsep pada Kinematika Gerak 1 Dimensi}

Berdasarkan jawaban mahasiswa yang terdapat pada gambar 1, ternyata masih terdapat pengertian antara jarak dan perpindahan yang masih tumpang tindih. Hal ini terlihat dari tingginya miskonsepsi mahasiswa untuk soal no 1 dan 2 yaitu sebesar $52,73 \%$ da $70,91 \%$ dari total 55 orang mahasiswa. Perbedaan antara konsep posisi dengan kelajuan suatu benda juga masih dirancukan oleh mahasiswa. Mereka masih menganggap jika dua objek memiliki posisi yang sama, maka mereka juga harus mempunyai kelajuan yang sama.

Ungkapan kelajuan konstan sudah cukup dipahami oleh mahasiswa. Hal ini terlihat dari persentase mahasiswa yang tahu konsep cukup besar dibanding mahasiswa yang mengalami miskonsepsi dan tidak tahu konsep. Jumlah mahasiswa yang tahu konsep sekitar 45,45\% .

Penguasaan pembacaan grafik sederhana pada mahasiswa semester 1 ini masih belum baik. Masih ada 56,36\% mahasiswa yang mengalami miskonsepsi. Hanya 14 orang yang bisa membaca grafik benda yang bergerak dengan kelajuan konstan.

Masih ada 60,00\% mahasiswa yang masih belum memahami konsep percepatan negatif (perlambatan) pada gerak lurus. Tiga puluh tiga orang dari seluruh mahasiswa menganggap arah percepatan suatu benda selalu sama dengan arah kecepatannya. Padahal arah kecepatan dan percepatan suatu benda yang bergerak tidak harus sama. Kita akan mendapatkan perlambatan jika kecepatan dan percepatan menunjuk ke arah yang berlawanan (Giancoli, 2001).

Beberapa mahasiswa masih mencampuradukkan konsep kecepatan dengan percepatan. Sejumlah 33 orang mahasiswa berpendapat bahwa jika mobil yang sedang diam memiliki kecepatan nol maka percepatannya juga nol. Padahal ketika menginjak rem, berarti kecepatan mobil berubah sehingga percepatannya tidak nol.

Perbedaan kelajuan dengan kecepatan juga masih belum sepenuhnya dipahami oleh mahasiswa. Ada 24 orang 
dari keseluruhan mahasiswa yang masih berpendapat bahwa mobil yang bergerak dengan kelajuan konstan juga bergerak dengan kecepatan konstan. Konsep arah pada kecepatan terabaikan. Mobil dapat bergerak dengan kelajuan konstan pada track melingkar, namun kecepatan yang dipengaruhi oleh arah mobil setiap saat akan berubah.

Miskonsepsi cukup tinggi dialami oleh mahasiswa pada konsep gerak vertikal ke atas. Mahasiswa semester 1 ini belum memahami bahwa yang bernilai nol pada titik tertinggi pada gerak vertikal ke atas adalah kecepatan, sedangkan percepatan tidak nol tapi tetap bernilai sebesar percepatan grafitasi. Sekitar $67,27 \%$ mahasiswa juga masih berpendapat bahwa kelajuan suatu benda yang dilempar vertikal ke atas pada suatu titik berbeda dengan kelajuannya saat turun pada tiitk yang sama.

Berdasarkan hasil jawaban mahasiswa untuk soal no 11, mayoritas mahasiswa $(80,00 \%)$ masih menganggap bahwa benda yang bermassa besar akan jatuh lebih cepat dibanding benda bermassa kecil (dalam keadaan tidak ada gangguan pada sistem selain gaya gravitasi). Hal ini secara tidak langsung menunjukan bahwa pemahaman siswa terhadap konsep gerak jatuh bebas belum sempurna. Adanya pemahaman benda bermassa besar akan jatuh lebih cepat dibandingkan benda dengan massa lebih kecil melahirkan interpretasi bahwa percepatan gravitasi tidak konstan. Hal ini merupakan asumsi yang tidak tepat.

Sekitar separoh dari mahasiswa semester $1(47,27 \%)$ mengalami miskonsepsi terhadap konsep kelajuan dan percepatan pada gerak jatuh bebas. Masih ada diantara mahasiswa yang berpendapat bahwa kelajuan dan percepatan pada gerak jatuh bebas selalu berubah. Padahal, pada gerak jatuh bebas yang bertambah secara linear terhadap waktu adalah kelajuan sedangkan percepatannya konstan (percepatan gravitasi).

\section{Analisis Pemahaman Mahasiswa Terhadap Konsep pada Kinematika Gerak dalam Dua Dimensi}

Masih banyak mahasiswa yang
belum memahami konsep besar kecepatan pada puncak suatu proyektil. Mahasiswa ini mengalami miskonsepsi karena berpendapat bahwa pada puncak proyektil peluru yang ditembakan akan berhenti bergerak. Padahal pada puncak proyektil, benda yang bergerak dengan lintasan parabola akan tetap bergerak pada arah horizontal. Bentuk lintasan gerak parabola juga masih belum dipahami mahasiswa dengan baik.

\section{Analisis Pemahaman Mahasiswa Ter- hadap Konsep Gerak dan Gaya (Dinamika)}

Pengertian fisis dari hukum Newton 1 belum dipahami dengan baik oleh mahasiswa. Lebih dari $65 \%$ mahasiswa mengalami miskonsepsi pada konsep hukum Newton 1 ini. Hal ini mungkin terjadi karena mahasiswa tidak bisa menterjemahkan pengertian hukum Newton 1 ke dalam kasus nyata.

Masih ada mahasiswa yang belum memahami konsep pasangan gaya aksi dan reaksi. Sekitar 27 orang mahasiswa mengalami miskonsepsi dengan menganggap bahwa gaya aksi dan reaksi bekerja pada benda yang sama dan bersifat saling meniadakan. Padahal pasangan gaya aksi dan reaksi harus bekerja pada benda yang berbeda dan tidak saling meniadakan.

Masih ada mahasiswa yang berpendapat bahwa benda yang diam di atas meja, berarti tidak ada gaya yang bekerja padanya. Terdapat 52,73\% mahasiswa yang berpendapat demikian. Mahasiswamahasiswa ini mungkin menganggap bahwa gaya selalu berkaitan langsung dengan gerak, sehingga benda yang diam berarti tidak mengalami gaya.

Konsep gaya normal dan gaya berat juga belum dipahami dengan baik oleh para mahasiswa. Masih ada maha- 
siwa yang berpendapat bahwa besarnya gaya normal selalu sama dengan gaya berat.

\section{Analisis Pemahaman Mahasiswa Ter- hadap Konsep Kerja dan Energi}

Mayoritas dari mahasiswa masih belum memahami konsep kerja pada fisika. Mahasiswa mengabaikan jarak tempuh sebagai salah satu faktor yang mempengaruhi besarnya kerja. Masih ada mahasiswa yang berpendapat bahwa energi benda yang diam di atas meja adalah nol. Mahasiswa melupakan konsep energi potensial yang dimiliki oleh benda diam di atas meja.

Sekitar separoh dari mahasiswa semester $1(47,27 \%)$ belum memahami konsep enegi kinetik pada suatu benda bergerak. Mereka berpendapat bahwa jika kecepatan suatu benda dilipatduakan, maka energi kinetiknya bertambah dua kali lipat. Mahasiswa-mahasiswa ini melupakan faktor kuadratik yang terdapat pada rumus energi kinetik dan hanya mengingat bahwa kecepatan dan energi kinetik "berbanding lurus". Hal ini bearti mahasiswa harus bisa lebih menganalisis dan memahami rumus matematik jika dirubah ke dalam kalimat.

\section{Analisis Pemahaman Mahasiswa Ter- hadap Konsep Momentum dan Impuls}

Hal yang menarik ditemukan pada hasil jawaban mahasiswa pada soal no 26 dan 28. Kedua soal ini adalah mengenai konsep impuls. Pada soal no 26, mengenai besarnya perubahan momentum(impuls) dan gaya pada saat hujan es, ada sekitar 70,91\% mahasiswa bisa menjawab dengan benar. Hal ini menandakan mahasiswa sudah memahami konsep impuls. Tapi pada soal no 28, masih ada sekitar 54,55\% mahasiswa yang mengalami miskonsepsi dengan menganggap bahwa impuls merupakan besaran yang dimiliki oleh benda yang bergerak. Hanya satu orang mahasiswa yang menjawab benar soal no 28 ini.
Impuls bukanlah besaran yang dimiliki oleh benda, tapi impuls adalah sesuatu yang dilakukan sebuah benda kepada benda lain ketika benda-benda tersebut berinteraksi. Impuls adalah gaya yang dikalikan dengan waktu (Giancoli, 2001).

Konsep energi potensial gravitasi juga belum dipahami oleh mahasiswa dengan baik. Hal ini terlihat dari hasil yang diperoleh pada soal no 27. Ada $50,91 \%$ mahasiswa yang masih mengalami miskonsepsi dengan menganggap bahwa besarnya energi potensial gravitasi tergantuk dari bentuk lintasan tempat benda berada. Padahal energi potensial grafitasi hanya bergantung kepada massa benda dan tinggi tempat benda tersebut berada.

\section{Analisis Pemahaman Mahasiswa Ter- hadap Konsep Energi Kinetik Rotasi}

Konsep energi kinetik rotasi belum sepenuhnya dipahami oleh mahasiswa. Masih ada mahasiswa yang masih menganggap massa benda mempengaruhi kecepatan sebuah benda tersebut menggelinding. Sekitar 52,73\% mahasiswa masih mengalami miskonsepsi terhadap konsep kelajuan pada menggelinding dengan meluncur. Yang mana kelajuan pada gerak meluncur lebih besar dari pada menggelinding karena seluruh energi potensial awalnya diubah menjadi energi kinetik translasi (tidak ada yang menjadi energi kinetik rotasi).

\section{PENUTUP}

Berdasarkan hasil analisa data, $80,00 \%$ mahasiswa mengalami miskonsepsi pada konsep waktu jatuh gerak jatuh bebas, 43,64\% tidak tahu konsep kecepatan dan percepatan pada gerak vertikal ke atas, dan 7,27\% mahasiswa yang tahu konsep hukum Newton 1. Kebanyakan mahasiswa masih cendrung mengalami miskonsepsi pada konsep jarak dan perpindahan, konsep posisi dan 
kecepatan, konsep bahwa kecepatan nol tidak selau mengakibatkan percepatan juga nol, konsep kecepatan dan percepatan pada gerak vertikal ke atas, konsep waktu jatuh pada gerak jatuh bebas, konsep besar kecepatan pada puncak proyektil, konsep gaya aksi dan

\section{DAFTAR RUJUKAN}

Akama. 2011. Daftar Nama Mahasiswa Program Studi Pendidikan Fisika tahun 2011. STAIN Batusangkar.

Depdiknas. 2005. KTSP Mata Pelajaran Fisika untuk SMA dan MA. Jakarta: Balitbang, Puskur, Departemen Pendidikan Nasional.

Demirci, N. 2005. A Study about Students' Misconceptions in Force and Motion Concepts by Incorporating a Web-assisted Physics Program, The Turkish Online Journal of Educational Technology (TOJET -www.tojet. net), 4, Issue 3, Article 7.

Giancoli, D. 2001. Fisika Jilid 1. Jakarta: Penerbit Erlangga.

Halloun, I. A., dan Hestenes, D. 1985. The Initial Knowledge State of College Physics Students, American Journal of Physics, 53, Issue 11, 1043-1055.

Hasan, S. D., Bagayoko, D., dan Kelley, E.L. 1999. Misconceptions and The Certainty of Response Index (CRI), Phys. Educ, 34(5), pp. 294-299.

Heon Kim, J.,Tae Park, S.,Lee, H dan Lee, H. 2005. Correcting Misconception Using Unrealistic Virtual Reality Simulation in Physics Education. Formatex.

Hestenes, D., Wells, M., Swackhamer, G. 1992. Force Concept Inventory. The Physics Teacher, 30, 141-158.

Liliawati, W dan Ramalis, T.R., 2008. Identifikasi Miskonsepsi Materi reaksi, hukum Newton 1, konsep kerja, konsep energi potensial dan energi potensial gravitasi serta konsep impuls. Dapat disimpulkan bahwa tingkat miskonsepsi mahasiswa semester 1 program studi Pendidikan Fisika STAIN Batusangkar cukup tinggi.

Masril, dan Asma, N. 2002. Pengungkapan Miskonsepsi Fisika Siswa Menggunakan Force Concept Inventory dan Certainty Response Index. Jurnal Fisika Himpunan Fisika Indonesia, B5, 1-3.

Muller, D. A., dan Sharma, M. D. 2007. Tackling Misconception in Introductory Physics Using Multimedia Presentations,. UniServe Science Teaching ang Learning Research Proceedings.

Osterholm, Magnus .2000. Qualitative Knowledge in Elementary Mechanics - a Study of Student in Linkoping. LIU-MAT-EX-00/01SE.

Sugiyono. 2007. Metode Penelitian Pendidikan (Pendekatan Kuantitatif, Kualitatif, dan $R \& D)$. Bandung: Alfabeta.

Suparno, P. 2005. Miskonsepsi dan Perubahan Konsep Pendidikan Fisika. Jakarta: Grasindo.

Tayubi, Y. R. 2005. Identifikasi Miskonsepsi pada Konsep-konsep Fisika Menggunakan Certainty of Response Index (CRI). Mimbar Pendidikan, 3/XXIV. 
